\title{
Genetic diversity of sago palm (Metroxylon sagu) accessions based on plastid cpDNA matK gene as DNA barcoding
}

\author{
BARAHIMA ABBAS ${ }^{1,2, \boldsymbol{\varphi}}$, IHWAN TJOLLI ${ }^{1}$, MUNARTI ${ }^{3}$ \\ ${ }^{1}$ Faculty of Agriculture, Universitas Papua. Jl. Gunung Salju, Manokwari 98314, West Papua, Indonesia. "email: b.abbas@unipa.ac.id \\ ${ }^{2}$ Post Graduate Program, Universitas Papua. Jl. Gunung Salju, Amban, Manokwari 98314, West Papua, Indonesia \\ ${ }^{3}$ Faculty of Teacher Training and Education Science, Universitas Pakuan. Jl. Pakuan, Bogor 16143, West Java, Indonesia
}

Manuscript received: 5 November 2019. Revision accepted: 22 December 2019.

\begin{abstract}
Abbas B, Tjolli I, Munarti. 2020. Genetic diversity of sago palm (Metroxylon sagu) accessions based on plastid cpDNA matK gene as DNA barcoding. Biodiversitas 21: 219-225. Metroxylon sagu Rottb is one of the plant species including in the Palmae family that deposits starch in the trunk. Sago palm was reported has high capability to produce a large amount of starch and large variation starch qualities which were mostly influenced by genetic factors. The objectives of this study are revealed sequence chloroplast DNA (cpDNA) associated with matK genes for the genetic diversity identification of sago palm accessions. Plant materials used in the studies were derived from Sago Research Center (SRC) collection. DNA extraction has adopted the procedure of Plant Genomic DNA Mini Kit. Polymerase chain reaction (PCR) was performed by using primer sets of MatK-1RKIM-f and MatK-3FKIM-r. DNA PCR product was sequenced by the $1^{\text {st }}$ Base Asia, Singapore. Results of the study showed that the cpDNA sequence associated with matK genes in the genome of sago palm showed differences among accessions. Molecular diversities of sago palm accessions based on matK gene showed sago palm accessions separated into two genotypes. Genotype-1 incorporated of ten individuals of 15 accessions and genotype- 2 incorporated five individuals of 15 accessions. A mutation site and deletion site occurred in the sequences of mat $\mathrm{K}$ gene of the Genotype-2. Ten of the 15 sequences of the matK gene (belong to Genotype-1) were registered in the GenBank, NCBI as DNA barcoding and authenticity of sago palm germplasm from Papua islands, Indonesia territorials.
\end{abstract}

Keywords: DNA barcoding, genetic diversity, matK gene, plastid cpDNA, sago palm

\section{INTRODUCTION}

Sago palm (Metroxylon sagu Rottb.) is included in the family of Arecaceae (Palmae) and the genus of Metroxylon. Beccari (1918) divides the Genus Metroxylon into two groups namely Eumetroxylon which has 3 species (M. sagu Rottb., M. rumphii Mart., and M. Squarossum Becc.) and Coelococcus has 6 species (M. warburgii Heim. M. Upoluense Becc., M. vitiense Benth, Et Hook, $M$. amicarum var. commune Becc., and var. majus Becc., $M$. salmonense Becc., and M. bougainvilense Becc.). Sago palm is a plant that produces large amounts of starch in the trunk. The ability of sago palm to produce starch is the highest compared to other starch producing plants. Karim et al. (2008) reported that sago starch production can reach 3 to 4 times higher than rice, corn, and wheat. The capabilities of sago palm accumulated large amounts of starch in the trunk were mostly influenced by genetic factors and sometimes influenced by environment. Yater et al. (2019) reported that sago palm growing on different ecological habitat showed morphological and starch production alike.

The genetic information of organisms in certain areas is very important to revealed to avoid conflicts of interest in germplasm ownership from a particular organization. Besides, the conservation of germplasm requires genetic diversity information to optimize and maintain germplasm efficiently. Genetic diversity information of organisms needs to be documented to maintain the sustainability of biological wealth and the existence of certain types of organisms, including sago palm. In the previous study, genetic marker was subjected to distinguished intraspecies of sago palm such as RAPD markers (Abbas et al. 2009), chloroplast DNA markers (Abbas et al. 2010), and mitochondrial nad2 gene markers (Abbas et al. 2019).

The important tools for recognizing genetic characteristic of plant and other organism is DNA barcoding. The DNA barcoding was reported as reliable tools for identification intraspecies level of rice (Singh and Banerjee 2018) and distinguished 54\% of 286 species by using matK and $r b c \mathrm{~L}$ as markers (Kuzmina et al. 2012).DNA barcoding is one or more short gene sequences taken from standard genome parts and used to identify species (Kress and Erickson 2008). Several genes that can be used for DNA coding of in the plants are genes in the chloroplast genome including the accD, matK, ndhJ, rpoB2, rpoC1, and ycf5 genes (Chase et al. 2007; Lahaye et al. 2008); rbcL (Kress and Erickson 2007); trnL intron (Taberlet et al. 2007); and trnH-psbA (Kress et al. 2005). The Consortium for the Barcoding of Life (CBoL) Plant Working Group (2009) recommends three genes, namely $r b c \mathrm{~L}, \operatorname{mat} \mathrm{K}$, and ITS, whereas in animal DNA sequences that can be used for barcoding are the cytochrome $\mathrm{C}$ oxidation (COI) genes in the mitochondrial genome. Kress and Erickson (2008) revealed that DNA barcoding can be used in the field of plant taxonomy and phylogenetics to identify plants more accurately than morphological identification. The DNA coding used in this study is matK 
(Maturase $\mathrm{K}$ ), which is a chloroplast gene and which is around 1500 base pairs (bp) located on the trnK intron. Hollingsworth et al. (2011) stated that currently the matK gene has been used as an important tool for examining the genetic diversity of intra-species and inter-species. This study aims to reveal the genetic diversity of Metroxylon sagu and relationship among sago palm accessions in intraspecies level based on plastid matK gene marker.

\section{MATERIALS AND METHODS}

\section{Plant materials}

Plant materials used in the studies were fifteen Sago genotypes derived from the Sago Palm Research Center (SRC) University of Papua (UNIPA) collections. Leaf samples were taken from accessions of sago palm in a growth russet stage. The Accession names are Sagu1, Sagu2, Sagu3, Sagu4, Sagu5, Sagu6, Sagu7, Sagu8, Sagu9, Sagu10, Sagu11, Sagu12, Sagu13, Sagu14, and Sagu15. The surface of the young leaf samples of sago palm accessions was wiped with an alcoholic tissue and brought into the Biotechnology Laboratory of Papua University, Manokwari, Indonesia for further use.

\section{DNA extraction}

The DNA extraction was done by following the procedure of Plant Genomic DNA Mini Kit (Geneaid 2012). The outlines of DNA extraction using Geneaid protocols are tissue dissociation, lysis, DNA binding, wash, and DNA elution. Tissue dissociation was done by grind the sample to a fine powder. As much as $20 \mathrm{mg}$ fine powder of the sample was transfer to a $1.5 \mathrm{ml}$ microcentrifuge tube, then following step 2, step 3, step 4, and step 5 in the protocols. The genomic DNAs were extracted and stored at $-20{ }^{\circ} \mathrm{C}$ freezer until ready used.

\section{Polymerase Chain Reaction (PCR) and sequencing}

Design of matK primer sequences used in this study is adopted from Kuzmina et al. (2012) and synthesized by Integrated DNA Technology (IDT), Singapore 117610. The Primer sequences, MatK-1RKIM-f 5'ACCCAGTCCATCTGGAAATCTTGG TTC-3 and MatK3FKIM-r 5'-CGTACAGTACTTT TGTGTTTACGAG-3', amplified chloroplast DNA associated with matK gene in the sago palm chloroplast genome. PCR mixtures were 50 $\mu 1$ total volume containing: 1 x PCR buffer contained 1.5 $\mathrm{mM} \mathrm{MgCl} 2,10 \mathrm{mM}$ dNTP mix, $5 \mu 1$ genomic DNA, $2.5 \mu 1$ forward and reverse primer, $1 \mu \mathrm{BSA}, 1 \mu \mathrm{l}$ DMSO, and 25 $\mu 1$ GoTaq Green. PCR condition is as follows: initial denaturation for 10 second at $80{ }^{\circ} \mathrm{C}$ and for 5 minutes at 94 ${ }^{\circ} \mathrm{C}$, followed by 40 cycles of denaturation for 30 second at $94{ }^{\circ} \mathrm{C}$, annealing for 30 seconds at $50{ }^{\circ} \mathrm{C}$, for 45 seconds extension at $72{ }^{\circ} \mathrm{C}$, the end of extension for 7 minutes at 72 ${ }^{\circ} \mathrm{C}$, and the end of PCR cycle for 1 minutes at $37{ }^{\circ} \mathrm{C}$. PCR amplification fragments were separated on $1 \%$ agarose gels by electrophoresis, staining was done using Ethidium Bromide and visualization by using UV illumination apparatus. Sequencing and purification of DNA PCR products were performed by 1st Base Asia, Singapore 117610

\section{Data analysis}

DNA sequences in the form of electropherogram were edited and checked to obtain the correct DNA sequence. Editing and proofreading sequences were performed by matching the peak color of the electropherogram to the sequence of nucleotides produced using Molecular Evolutionary Genetics Analysis (MEGA) version 7.0 software (Kumar et al. 2016). Each sequence in this study was obtained from the forward and reverse sequences of each sample. The editing result of a nucleotide sequence is stored in the fasta file format. Cluster alignment was performed based on Clustal W with MEGA7 software. The evolutionary history was inferred using the Minimum Evolution (ME) method (Rzhetsky and Nei 1992). The evolutionary distances were computed using the Maximum Composite Likelihood method (Tamura et al. 2004) and are in the units of the number of base substitutions per site. The $\mathrm{ME}$ tree was searched using the Close-NeighborInterchange (CNI) algorithm (Nei and Kumar 2000) at a search level of 1 . The Neighbor-joining algorithm (Saitou and Nei 1987) was used to generate the initial tree and bootstrap consensus tree was performed 500 replications (Felsenstein 1985). The analysis involved nucleotide sequences of 15 sago palm accessions. Codon positions included were $1 \mathrm{st}+2 \mathrm{nd}+3 \mathrm{rd}+$ Noncoding. All positions containing gaps and missing data were eliminated. There were a total of 604 positions in the final dataset. Evolutionary analyses based on the mat $\mathrm{K}$ gene of sago palm accessions were conducted in MEGA7 (Kumar et al. 2016).

\section{RESULTS AND DISCUSSION}

\section{Nucleotide sequence of mat $\mathrm{K}$ genes}

Alignments of the chloroplast sequences associated with matK genes within species of sago palm were presented in Figure 1. The alignment in Figure 1 shows two genotypes based on the matK gene sequence. Genotype 1 was identified in Sagu01, Sagu02, Sagu08, Sagu12, and Sagu15 and Genotype-2 was identified in Sagu03, Sagu04, Sagu05, Sagu06, Sagu07, Sagu09, Sagu10, Sagu11, Sagu13, and Sagu14. Figure 1 showed that Genotype-1 was identified by Thymine (T) base in the position of nucleotide $5^{\text {th }}$ base and $16^{\text {th }}$ base. On the other hand, Genotype-2 was identified by adenine (A) base in the position of nucleotide base $5^{\text {th }}$ and nucleotide deletion in the position of nucleotide base $16^{\text {th }}$. These features showed that $m a t \mathrm{~K}$ gene in the chloroplast genome of sago palm is highly conserved because of just two sites of nucleotide sequence differences of 604 bases length. Selvaraj et al. (2008) reported that $m a t \mathrm{~K}$ in the chloroplast genome is highly conserved and Provan et al. (1999) stated very low mutation rates which range from $3.2 \times 10^{-5}$ to $7.9 \times 10^{-5}$. Both of chloroplast genome and mitochondrial genome of sago palm belonging to highly conserved DNA sequences. Abbas et al. (2019) observed that no differentiation among 
sago palm accessions in the mitochondrial genome based on nad 2 gene marker. However, the nuclear genome of sago palm from Papua islands highly varied identified by Random Amplified Polymorphic DNA (RAPD) marker (Riyanto et al. 2018; Abbas 2018; Abbas et al. 2009).

The nucleotide sequencing results of an organism will be accepted and registered in the GenBank after verification and showed clearly perfect. This study, the nucleotides sequence mat $\mathrm{K}$ genes of sago palm genotypes1 were accepted and registered in the GenBank, NCBI with the sequence number BankIt2219548 Sagu03 MK860160, BankIt2219548 Sagu04 MK860161, BankIt2219548 Sagu05 MK860162, BankIt2219548 Sagu06 MK860163, BankIt2219548 Sagu07 MK860164, BankIt2219548 Sagu09 MK860165, BankIt2219548 Sagu10 MK860166, BankIt2219548 Sagu11 MK860167, BankIt2219548 Sagu13 MK860168, BankIt2219548 Sagu14 MK860169. The sequences of matK genes of sago palm genotypes-two were verified through repetitions process of DNA extraction, PCR, and DNA sequencing to ensure the sequence stability. After three times repetitions of the DNA sequencing process, the results showed the same basic arrangement as before. Therefore, based on the verification results, it is confirmed that the accession of Sagu01, Sagu02, Sagu08, Sagu12, and Sagu15 has mutated in the position of two nucleotides base in the DNA sequence arrangement, marked with black box sequences (Figure 2). The first nucleotide base mutation is thymine to the base of adenine and the second nucleotide base mutation is the deletion of thymine base, marked as gap or dashes (Figure 2 ). The chloroplast genome identification in the previous studies showed that plant chloroplast genome possesses a low mutation rate, a little compactness, large size, and high rearrange structure (Darracq et al. 2011). One of the reasons caused a low mutation rate of chloroplast genome is uniparentally inherited (Savolainen et al. 1995; Viard et al. 2001)

\section{0 \\ 600 \\ 610 \\ 620 \\ 630 \\ 640 \\ 650 \\ 660 \\ GTTACTAAAAAATTCGATACCAGAGTCCCAGTTATTCCTCTTATTGAATCATTGTCTAAAGCAAAATTT TGTACCGTATC}

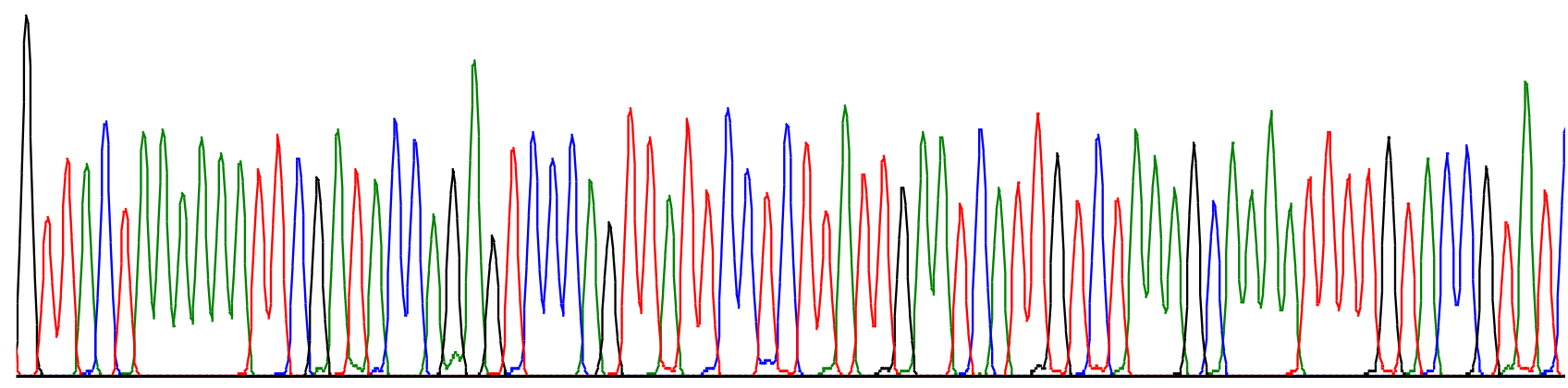

Figure 1. Performance of electropherogram sequencing result of sago palm accessions based on plastid matK gene

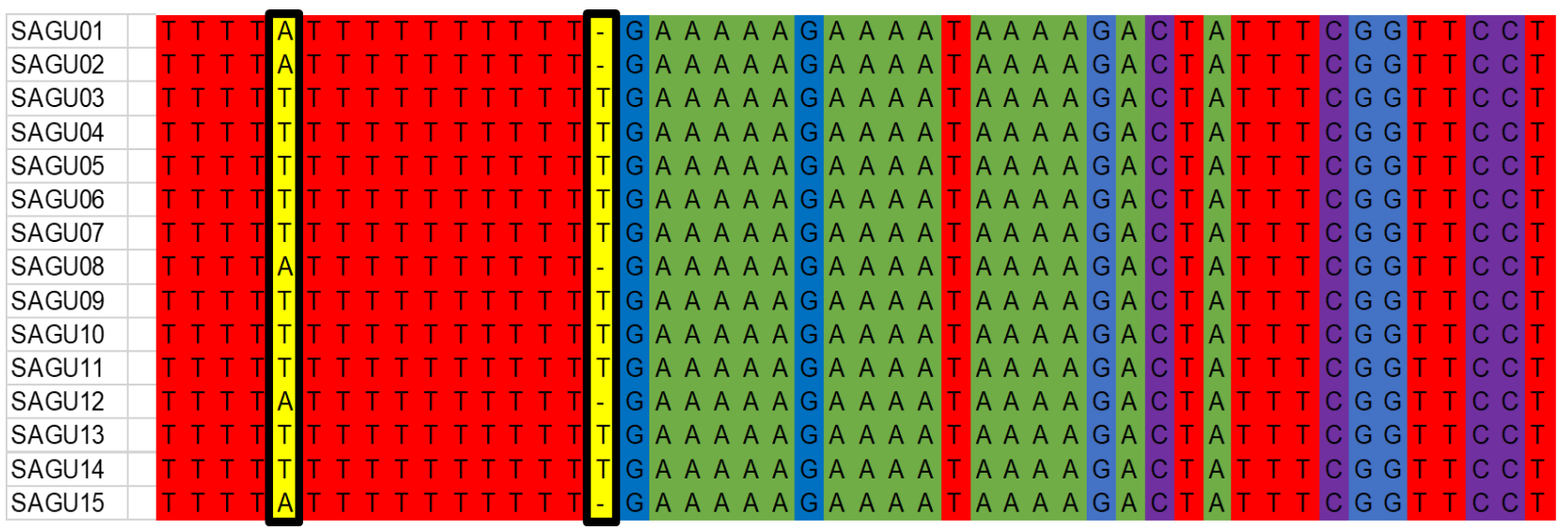

Figure 2. DNA sequences of sago palm genotype-1 and genotype- 2 based on matK gene. The black boxes are segregation sites and deletion sites. Genotype-1 is Sagu03, Sagu04, Sagu05, Sagu06, Sagu07, Sagu09, Sagu10, Sagu11, Sagu13, and Sagu14. Genotype-2 is Sagu01, Sagu02, Sagu08, Sagu12, and Sagu15. 
Table 1. Tajima's neutrality test by using 15 nucleotide sequence of sago palm accessions based on plastid matK gene

\begin{tabular}{cccccc}
\hline $\mathbf{m}$ & $\mathbf{S}$ & $\mathbf{p s}$ & $\boldsymbol{\Theta}$ & $\boldsymbol{\Pi}$ & $\mathbf{D}$ \\
\hline 15 & 1 & 0.001656 & 0.000509 & 0.000788 & 1.122408 \\
\hline
\end{tabular}

Notes: $\mathrm{m}=$ number of sequences, $\mathrm{S}=$ Number of segregating sites, $\mathrm{ps}=\mathrm{S} / \mathrm{n}, \Theta=\mathrm{ps} / \mathrm{a} 1, \pi=$ nucleotide diversity, and $\mathrm{D}$ is the Tajima test statistic (Tajima 1989)

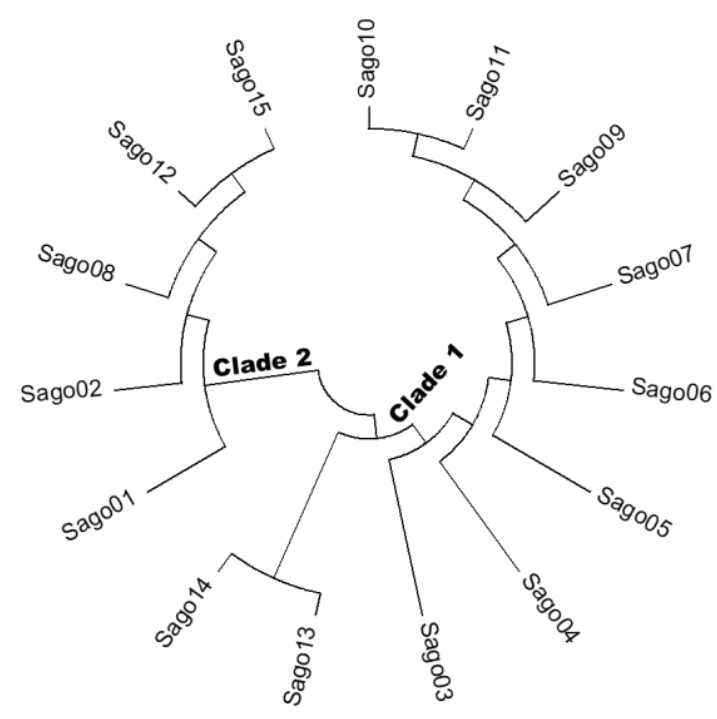

Figure 3. Evolutionary relationships of sago palm accessions based on matK genes in the plastid genome

\section{Genetic diversities of sago palm}

Nucleotide diversities of sago palm sequences based on the $m a t \mathrm{~K}$ gene as barcoding were observed as low value that is 0.000788 ; only one number of segregation sites and one number of deletion sites (Table 1). In the previous study using large amount of sago palm samples from around Indonesian territorial using cpDNA marker, a low variation was also reported and specific haplotype was found exist in the Papua island (Abbas et al. 2010).

Substitution patterns and rates were estimated under the Tamura and Nei (1993) model (+G). A discrete Gamma distribution was used to model evolutionary rate differences among sites (5 categories, $[+\mathrm{G}]$ ). The mean value of the evolutionary rates in these categories were $0.90,0.96,1.00,1.04,1.10$ substitutions per site. The nucleotide frequencies are $\mathrm{A}=29.8 \%, \mathrm{~T}=36.8 \%, \mathrm{C}=$ $17.5 \%$, and $\mathrm{G}=15.9 \%$. The highest nucleotide frequencies are Thymine $(\mathrm{T})$ and the lowest nucleotide frequencies are Guanine (G) (Table 2).

The probability of rejecting the null hypothesis of the strict-neutrality $(\mathrm{dN}=\mathrm{dS})$ is shown below diagonal, while the test statistic $(\mathrm{dN}-\mathrm{dS})$ is shown above the diagonal, in which $\mathrm{dS}$ and $\mathrm{dN}$ are the numbers of synonymous and nonsynonymous substitutions per site, respectively (Table 3 ). The variance of the difference was computed using the analytical method. Analyses were conducted using the NeiGojobori method (Nei and Gojobori (1986). The probability of 1.000 values (below diagonal) indicated rejecting the null hypothesis that means plastid matK loci of the sago palm in the intra-species level is distinctly different. On the other hand, the probability of 0.319 values represented the null hypothesis. Therefore, the matK gene loci can be used as DNA barcoding for sago palm. The previous studies reported that DNA barcoding studies on the sand rice (Agriophyllum squarrosum (L.) Moq) identified $1.8 \%$ variabilities by using matK marker (Genievskaya et al. 2017), intra-specific mangroves were identified had $0.2 \%$ variabilities by using matK marker (Saddhe et al. 2016), and vascular plant was identified had $0.04 \%$ variabilities by using matK marker (Kuzmina et al. 2012).

\section{Genetic relationship}

The evolutionary distances of 15 sago palm accessions based on matK genes showed that the genotype- 1 and genotype- 2 were different with amount 0.002 evolutionary distances (Table 4). The relationships among 15 sago palm accessions were separated into two clades and the optimal tree with the sum of branch length $=0.00165716$ is shown (Figure 3). Clade-1 is incorporated sago palm accessions number Sagu03, Sagu04, Sagu05, Sagu06, Sagu07, Sagu09, Sagu10, Sagu11, Sagu13, and Sagu14. Clade-1 which were identified as genotype-1. The clade- 2 is incorporated sago palm accessions number Sagu01, Sagu02, Sagu08, Sagu12, and Sagu15, identified as Genotype-2 (Figure 3). The differentiation between Genotype-1 and Genotype-2 may occur in the process of cpDNA replication for a long time. In the previous studies showed that the interspecific sequence divergence of Astragalus was reached 3.92\% (Liston 1992). The specific chloroplast genes of Conifers were detected at 23, 26, 38, 48,67 , and 25 site changes in the $f r x \mathrm{C}, r b c \mathrm{~L}, p s b \mathrm{~A}, p s b \mathrm{D}$, $\operatorname{trnK}$, and $16 \mathrm{~S}$ respectively among species of Conifer (Tsumura et al. 1995). Segregations in the DNA plastid of matK gene in the sago palm genotype-2 were in harmony with phylogenetic of Dipterocarpaceae based on the matK gene (Harnelly et al. 2018), and corresponds to the DNA barcode by using the matK gene in Pandanus (Zebua et al. 2019). Therefore, the DNA Barcode by using plastid matK gene can be used to determine intra-species of the sago palm.

In conclusion, this study indicated that cpDNA sequences associated with matK genes in the genome of sago palm were shown low differences among accessions. Nucleotide diversities of sago palm sequences based on the matK gene as barcoding were observed at 0.000788 value. Molecular phylogenetic of sago palm based on the matK gene markers showed that the sago palm intra-species incorporated into two clades. DNA barcoding using matK gene might be used as a tool for intra-species identification of the sago palm. 
Table 2. Nucleotide composition of 15 sago palm accessions based on plastid matK gene

\begin{tabular}{|c|c|c|c|c|c|c|c|c|c|c|c|c|c|c|c|c|c|c|c|c|}
\hline & $\mathbf{T}(\mathbf{U})$ & C & $\mathbf{A}$ & $\mathbf{G}$ & Total & T-1 & C-1 & A-1 & G-1 & Pos \#1 & T-2 & C-2 & A-2 & G-2 & Pos \#2 & T-3 & $\mathrm{C}-3$ & A-3 & G-3 & Pos \#3 \\
\hline Sagu01 & 36.6 & 17.5 & 30.0 & 15.9 & 604.0 & 33 & 22.3 & 26.7 & 18.3 & 202.0 & 36 & 18.3 & 31.7 & 13.9 & 202.0 & 41 & 12.0 & 31.5 & 15.5 & 200.0 \\
\hline Sagu02 & 36.6 & 17.5 & 30.0 & 15.9 & 604.0 & 33 & 22.3 & 26.7 & 18.3 & 202.0 & 36 & 18.3 & 31.7 & 13.9 & 202.0 & 41 & 12.0 & 31.5 & 15.5 & 200.0 \\
\hline Sagu03 & 36.9 & 17.5 & 29.8 & 15.9 & 605.0 & 33 & 22.3 & 26.2 & 18.3 & 202.0 & 36 & 18.3 & 31.7 & 13.9 & 202.0 & 41 & 11.9 & 31.3 & 15.4 & 201.0 \\
\hline Sagu04 & 36.9 & 17.5 & 29.8 & 15.9 & 605.0 & 33 & 22.3 & 26.2 & 18.3 & 202.0 & 36 & 18.3 & 31.7 & 13.9 & 202.0 & 41 & 11.9 & 31.3 & 15.4 & 201.0 \\
\hline Sagu05 & 36.9 & 17.5 & 29.8 & 15.9 & 605.0 & 33 & 22.3 & 26.2 & 18.3 & 202.0 & 36 & 18.3 & 31.7 & 13.9 & 202.0 & 41 & 11.9 & 31.3 & 15.4 & 201.0 \\
\hline Sagu06 & 36.9 & 17.5 & 29.8 & 15.9 & 605.0 & 33 & 22.3 & 26.2 & 18.3 & 202.0 & 36 & 18.3 & 31.7 & 13.9 & 202.0 & 41 & 11.9 & 31.3 & 15.4 & 201.0 \\
\hline Sagu07 & 36.9 & 17.5 & 29.8 & 15.9 & 605.0 & 33 & 22.3 & 26.2 & 18.3 & 202.0 & 36 & 18.3 & 31.7 & 13.9 & 202.0 & 41 & 11.9 & 31.3 & 15.4 & 201.0 \\
\hline Sagu08 & 36.6 & 17.5 & 30.0 & 15.9 & 604.0 & 33 & 22.3 & 26.7 & 18.3 & 202.0 & 36 & 18.3 & 31.7 & 13.9 & 202.0 & 41 & 12.0 & 31.5 & 15.5 & 200.0 \\
\hline Sagu09 & 36.9 & 17.5 & 29.8 & 15.9 & 605.0 & 33 & 22.3 & 26.2 & 18.3 & 202.0 & 36 & 18.3 & 31.7 & 13.9 & 202.0 & 41 & 11.9 & 31.3 & 15.4 & 201.0 \\
\hline Sagu10 & 36.9 & 17.5 & 29.8 & 15.9 & 605.0 & 33 & 22.3 & 26.2 & 18.3 & 202.0 & 36 & 18.3 & 31.7 & 13.9 & 202.0 & 41 & 11.9 & 31.3 & 15.4 & 201.0 \\
\hline Sagu11 & 36.9 & 17.5 & 29.8 & 15.9 & 605.0 & 33 & 22.3 & 26.2 & 18.3 & 202.0 & 36 & 18.3 & 31.7 & 13.9 & 202.0 & 41 & 11.9 & 31.3 & 15.4 & 201.0 \\
\hline Sagu12 & 36.6 & 17.5 & 30.0 & 15.9 & 604.0 & 33 & 22.3 & 26.7 & 18.3 & 202.0 & 36 & 18.3 & 31.7 & 13.9 & 202.0 & 41 & 12.0 & 31.5 & 15.5 & 200.0 \\
\hline Sagu13 & 36.9 & 17.5 & 29.8 & 15.9 & 605.0 & 33 & 22.3 & 26.2 & 18.3 & 202.0 & 36 & 18.3 & 31.7 & 13.9 & 202.0 & 41 & 11.9 & 31.3 & 15.4 & 201.0 \\
\hline Sagu14 & 36.9 & 17.5 & 29.8 & 15.9 & 605.0 & 33 & 22.3 & 26.2 & 18.3 & 202.0 & 36 & 18.3 & 31.7 & 13.9 & 202.0 & 41 & 11.9 & 31.3 & 15.4 & 201.0 \\
\hline Sagu15 & 36.6 & 17.5 & 30.0 & 15.9 & 604.0 & 33 & 22.3 & 26.7 & 18.3 & 202.0 & 36 & 18.3 & 31.7 & 13.9 & 202.0 & 41 & 12.0 & 31.5 & 15.5 & 200.0 \\
\hline Avg. & 36.8 & 17.5 & 29.8 & 15.9 & 604.7 & 33 & 22.3 & 26.4 & 18.3 & 202.0 & 36 & 18.3 & 31.7 & 13.9 & 202.0 & 41 & 12.0 & 31.4 & 15.4 & 200.7 \\
\hline
\end{tabular}

Table 3. Codon-based Test of Neutrality for analysis between sequences of sago palm intra-species by using Z-Test of Neutral evolution

\begin{tabular}{|c|c|c|c|c|c|c|c|c|c|c|c|c|c|c|c|}
\hline Acces. & Sagu01 & Sagu02 & Sagu03 & Sagu04 & Sagu05 & Sagu06 & Sagu07 & Sagu08 & Sagu09 & Sagu10 & Sagu11 & Sagu12 & Sagu13 & Sagu14 & Sagu15 \\
\hline Sagu01 & 1.000 & 0.000 & 1.001 & 1.001 & 1.001 & 1.001 & 1.001 & 0.000 & 1.001 & 1.001 & 1.001 & 0.000 & 1.001 & 1.001 & 0.000 \\
\hline Sagu02 & 1.000 & 1.000 & 1.001 & 1.001 & 1.001 & 1.001 & 1.001 & 0.000 & 1.001 & 1.001 & 1.001 & 0.000 & 1.001 & 1.001 & 0.000 \\
\hline Sagu03 & 0.319 & 0.319 & 1.000 & 0.000 & 0.000 & 0.000 & 0.000 & 1.001 & 0.000 & 0.000 & 0.000 & 1.001 & 0.000 & 0.000 & 1.001 \\
\hline Sagu04 & 0.319 & 0.319 & 1.000 & 1.000 & 0.000 & 0.000 & 0.000 & 1.001 & 0.000 & 0.000 & 0.000 & 1.001 & 0.000 & 0.000 & 1.001 \\
\hline Sagu05 & 0.319 & 0.319 & 1.000 & 1.000 & 1.000 & 0.000 & 0.000 & 1.001 & 0.000 & 0.000 & 0.000 & 1.001 & 0.000 & 0.000 & 1.001 \\
\hline Sagu06 & 0.319 & 0.319 & 1.000 & 1.000 & 1.000 & 1.000 & 0.000 & 1.001 & 0.000 & 0.000 & 0.000 & 1.001 & 0.000 & 0.000 & 1.001 \\
\hline Sagu07 & 0.319 & 0.319 & 1.000 & 1.000 & 1.000 & 1.000 & 1.000 & 1.001 & 0.000 & 0.000 & 0.000 & 1.001 & 0.000 & 0.000 & 1.001 \\
\hline Sagu08 & 1.000 & 1.000 & 0.319 & 0.319 & 0.319 & 0.319 & 0.319 & 1.000 & 1.001 & 1.001 & 1.001 & 0.000 & 1.001 & 1.001 & 0.000 \\
\hline Sagu09 & 0.319 & 0.319 & 1.000 & 1.000 & 1.000 & 1.000 & 1.000 & 0.319 & 1.000 & 0.000 & 0.000 & 1.001 & 0.000 & 0.000 & 1.001 \\
\hline Sagu10 & 0.319 & 0.319 & 1.000 & 1.000 & 1.000 & 1.000 & 1.000 & 0.319 & 1.000 & 1.000 & 0.000 & 1.001 & 0.000 & 0.000 & 1.001 \\
\hline Sagu11 & 0.319 & 0.319 & 1.000 & 1.000 & 1.000 & 1.000 & 1.000 & 0.319 & 1.000 & 1.000 & 1.000 & 1.001 & 0.000 & 0.000 & 1.001 \\
\hline Sagu12 & 1.000 & 1.000 & 0.319 & 0.319 & 0.319 & 0.319 & 0.319 & 1.000 & 0.319 & 0.319 & 0.319 & 1.000 & 1.001 & 1.001 & 0.000 \\
\hline Sagu13 & 0.319 & 0.319 & 1.000 & 1.000 & 1.000 & 1.000 & 1.000 & 0.319 & 1.000 & 1.000 & 1.000 & 0.319 & 1.000 & 0.000 & 1.001 \\
\hline Sagu14 & 0.319 & 0.319 & 1.000 & 1.000 & 1.000 & 1.000 & 1.000 & 0.319 & 1.000 & 1.000 & 1.000 & 0.319 & 1.000 & 1.000 & 1.001 \\
\hline Sagu15 & 1.000 & 1.000 & 0.319 & 0.319 & 0.319 & 0.319 & 0.319 & 1.000 & 0.319 & 0.319 & 0.319 & 1.000 & 0.319 & 0.319 & 1.000 \\
\hline
\end{tabular}


Table 4. The evolutionary distances of sago palm based on matK gene were computed using the Maximum Composite Likelihood method

\begin{tabular}{|c|c|c|c|c|c|c|c|c|c|c|c|c|c|c|c|}
\hline Acces. & Sagu01 & Sagu02 & Sagu03 & Sagu04 & Sagu05 & Sagu06 & Sagu07 & Sagu08 & Sagu09 & Sagu10 & Sagu11 & Sagu12 & Sagu13 & Sagu14 & Sagu15 \\
\hline Sagu01 & 0.000 & & & & & & & & & & & & & & \\
\hline Sagu02 & 0.000 & 0.000 & & & & & & & & & & & & & \\
\hline Sagu03 & 0.002 & 0.002 & 0.000 & & & & & & & & & & & & \\
\hline Sagu04 & 0.002 & 0.002 & 0.000 & 0.000 & & & & & & & & & & & \\
\hline Sagu05 & 0.002 & 0.002 & 0.000 & 0.000 & 0.000 & & & & & & & & & & \\
\hline Sagu06 & 0.002 & 0.002 & 0.000 & 0.000 & 0.000 & 0.000 & & & & & & & & & \\
\hline Sagu07 & 0.002 & 0.002 & 0.000 & 0.000 & 0.000 & 0.000 & 0.000 & & & & & & & & \\
\hline Sagu08 & 0.000 & 0.000 & 0.002 & 0.002 & 0.002 & 0.002 & 0.002 & 0.000 & & & & & & & \\
\hline Sagu09 & 0.002 & 0.002 & 0.000 & 0.000 & 0.000 & 0.000 & 0.000 & 0.002 & 0.000 & & & & & & \\
\hline Sagu10 & 0.002 & 0.002 & 0.000 & 0.000 & 0.000 & 0.000 & 0.000 & 0.002 & 0.000 & 0.000 & & & & & \\
\hline Sagu11 & 0.002 & 0.002 & 0.000 & 0.000 & 0.000 & 0.000 & 0.000 & 0.002 & 0.000 & 0.000 & 0.000 & & & & \\
\hline Sagu12 & 0.000 & 0.000 & 0.002 & 0.002 & 0.002 & 0.002 & 0.002 & 0.000 & 0.002 & 0.002 & 0.002 & 0.000 & & & \\
\hline Sagu13 & 0.002 & 0.002 & 0.000 & 0.000 & 0.000 & 0.000 & 0.000 & 0.002 & 0.000 & 0.000 & 0.000 & 0.002 & 0.000 & & \\
\hline Sagu14 & 0.002 & 0.002 & 0.000 & 0.000 & 0.000 & 0.000 & 0.000 & 0.002 & 0.000 & 0.000 & 0.000 & 0.002 & 0.000 & 0.000 & \\
\hline Sagu15 & 0.000 & 0.000 & 0.002 & 0.002 & 0.002 & 0.002 & 0.002 & 0.000 & 0.002 & 0.002 & 0.002 & 0.000 & 0.002 & 0.002 & 0.000 \\
\hline
\end{tabular}




\section{ACKNOWLEDGEMENTS}

The research was financially funded by the Directorate General Strengthen Research and Development Republic Indonesia with contract No. 198/SP2H/LT/DRPM/2019. The authors thank the Research Development Project Manager and Food Security Service of West Papua Province, Indonesia.

\section{REFERENCES}

Abbas B, Bintoro MH, Sudarosono, Surahman M, Ehara H. 2009. Genetic relationship of sago palm (Metroxylon sagu Rottb.) in Indonesia based on RAPD markers. Biodiversitas 10 (4): 168-174. DOI: 10.13057/biodiv/d100402

Abbas B, Renwarin Y, Bintoro MH, Sudarsono, Surahman M, Ehara H. 2010. Genetic Diversity of Sago Palm in Indonesia Based on Chloroplast DNA (CpDNA) Markers. Biodiversitas 11 (3): 112-17. DOI: $10.13057 /$ biodiv/d110302.

Abbas B, Tjolli I, Dailami M, Munarti. 2019. Phylogenetic of sago palm (Metroxylon sagu) and others monocotyledon based on mitochondrial Nad2 gene markers. Biodiversitas 20 (8): 2249-2256. DOI: 10.13057/biodiv/d200820.

Abbas B. 2018. Sago palm genetic resource diversity in Indonesia. In Ehara H, Toyoda Y, Johnson D. (eds.). Sago Palm: Multiple Contributions to Food Security and Sustainable Livelihoods. Springer, Singapore.

Beccari O. 1918. Asiatic palms. Lepidocaryeae. Ann Roy Bot Gard Calcutta 12: 156-195.

Chase MW, Cowan RS, Hollingsworth PM, Berg CVD, Madrin'an S, Petersen G, Seberg O, Jorsensen T, Cameron KM, Carine M, Pedersen N, Hedderson TAJ, Conrad F, Salazar GA, Richardson JE, Hollingsworth ML, Barraclough TG, Kelly L, Wilkinson M. 2007. A proposal for a standardized protocol to barcode all land plants. Taxon 56: 295-299.

Darracq A, Varre JS, Drouard LM, Courseaux A, Castric V, Laprade PS, Oztas S, Lenoble P, Barbe B, Touzet P. 2011. Structural and conten diversity of mitochondrial genome in beet: A comparative genomic analysis. Genome Biol Evol 3: 723-736

Felsenstein J. 1985. Confidence limits on phylogenies: An approach using the bootstrap. Evolution 39: 783-791.

Genievskaya Y, Abugalieva S, Zhubanysheva A, Turuspekov Y. 2017. Morphological description and DNA barcoding study of sand rice (Agriophyllum squarrosum, Chenopodiaceae) collected in Kazakhstan. BMC Plant Biol 17 (1): 177-185. DOI 10.1186/s12870017-1132-1.

Harnelly E, Thomy Z, Fathiya N. 2018. Phylogenetic analysis of Dipterocarpaceae in Ketambe Research Station, Gunung Leuser National Park (Sumatra, Indonesia) based on rbcL and matK genes. Biodiversitas 19: 1074-1080. DOI: 10.13057/biodiv/d190340.

Hollingsworth PM, Graham SW, Little DP. 2011. Choosing and Using a Plant DNA Barcode. PLoS ONE. 6 (5): 1-13.

Karim AA, Pei-Lang Tie A, Manan DMA, Zaidul ISM. 2008. Starch from the sago (Metroxylon sagu) palm tree-properties, prospects and challenges as a source for food and other uses. Compr Rev Food Sci Food Saf 7: 215-228

Kress WJ, Erickson DL. 2008. DNA DNA barcoding: Genes, genomics, and bioinformatics. Proc Natl Acad Sci USA 105: 2761-2762.

Kress W J, Erickson DL. 2007. A two-locus global DNA barcode for land plants: The coding rbcL gene complements the noncoding trnH-psbA spacer region. PLoS ONE 2: e508. DOI: 10.1371/journal.pone.0000508.

Kress WJ, Wurdack KJ, Zimmer EA, Weigt LA, Janzen DH. 2005. Use of DNA barcodes to identify flowering plants. Proc Natl Acad Sci USA 102: 8369-8374.
Kumar S, Stecher G, Tamura K. 2016. MEGA7: Molecular Evolutionary Genetics Analysis version 7.0 for bigger datasets. Mol Biol Evol 33: 1870-1874

Kuzmina ML, Johnson KL, Barron HR, Herbert PDN. 2012. Identification of vascular plants of Churchill, Manitoba, using a DNA barcode library. BMC Ecology 12 (25): 1-11. DOI: 10.1186/1472-6785-12-25.

Lahaye R, Bank MVD, Bogarin D, Warner J, Pupulin F, Gigot G, Maurin O, Duthoit S, Barraclough TG, Savolainen V. 2008. DNA barcoding the floras of biodiversity hotspots. Proc Natl Acad Sci USA 105 (8): 2761-2762.

Liston A. 1992. Variation in the chloroplast genes RPOC1 and RPOC2 of the genus Astragalus (Fabaceae): Evidence from restriction site mapping of a PCR amplified fragment. Am J Bot 79: 953-961.

Nei M, Gojobori T. 1986. Simple methods for estimating the numbers of synonymous and nonsynonymous nucleotide substitutions. Mol Biol Evol 3: 418-426.

Nei M, Kumar S. 2000. Molecular Evolution and Phylogenetics. Oxford University Press, New York.

Provan J, Soranzo N, Wilson NJ, Goldstein DB, Powel W. 1999. A low mutation rate for chloroplast microsatellites. Genetics 153: 943-947.

Riyanto R, Widodo I, Abbas B. 2018. Morphology, growth and genetic variations of sago palm (Metroxylon sagu) seedlings derived from seeds. Biodiversitas 19: 602-608. DOI: 10.13057/biodiv/d190241.

Rzhetsky A, Nei M. 1992. A simple method for estimating and testing minimum evolution trees. Mol Biol Evol 9: 945-967.

Saddhe AA, Jamdade AR, Kumar K. 2016. Assessment of mangroves from Goa, west coast India using DNA barcode. SpringerOpen 5: 1554-1564. DOI: 10.1186/s40064-016-3191-4.

Saitou N, Nei M. 1987. The neighbor-joining method: A new method for reconstructing phylogenetic trees. Mol Biol Evol 4: 406-425.

Savolainen V, Corbaz R, Moncousin C, Spchiger R, Manen JF. 1995. Chloroplast DNA variation and parentage analysis in 55 apples. Theor Appl Genet 90: 1138-1141

Selvaraj D, Sarma RK, Sathishkumar R. 2008. Phylogenetic analysis of chloroplast matK gene from Zingiberaceae for plant DNA barcoding. Bioinformation 3 (1): 24-27.

Singh J, Banerjee S. 2018. Utility of DNA barcoding tools for conservation and molecular identification of intraspecies of rice genotypes belonging to Chhattisgarh using $r b c \mathrm{~L}$ and $m a t \mathrm{~K}$ gene sequences. Plant Arch 18: 69-75.

Taberlet P, Coissac E, Pompanon F, Gielly L, Miquel C, Valentini A, Vermat T, Corthier, Brochmann C, Willerslev E. 2007. Power and limitations of the chloroplast trnL (UAA) intron for plant DNA barcoding. Nucleic Acids Res 35 (3): 1-8. DOI: 10.1093/nar/gk1938

Tajima F. 1989. Statistical methods to test for nucleotide mutation hypothesis by DNA polymorphism. Genetics 123 (3): 585-595.

Tamura K, Nei M. 1993. Estimation of the number of nucleotide substitutions in the control region of mitochondrial DNA in humans and chimpanzees. Mol Biol Evol 10: 512-526.

Tamura K, Nei M, Kumar S. 2004. Prospects for inferring very large phylogenies by using the neighbor-joining method. Proc Natl Acad Sci USA 101: 11030-11035.

Tsumura Y, Yoshimura K, Tomaru N, Ohba K. 1995. Molecular phylogeny of conifer using RFLP analysis of PCR-amplified specific chloroplast genes. Theor Appl Genet 91: 1222-1236.

Viard F, El-Kassaby YA, Ritland A. 2001. Diversity and genetic structure in populations of Pseudotsuga menziesii (Pinaceae) at chloroplast microsatellite loci. Genome 44: 336-344.

Yater T, Tubur HW, Meliala C, Abbas B. 2019. Short Communication: A comparative study of phenotypes and starch production in sago palm (Metroxylon sagu) growing naturally in temporarily inundated and non-inundated areas of South Sorong, Indonesia. Biodiversitas 20: 1121-1126. DOI: 10.13057/biodiv/d200425.

Zebua LI, Gunaedi T, Budi IM, Lunga N. 2019. The DNA barcode of red fruit pandan (Pandanaceae) cultivar from Wamena, Papua Province, Indonesia based on matK gene. Biodiversitas 20: 3405-3412. DOI: 10.13057/biodiv/d201138. 